\title{
Research on the role of excellent traditional culture on college students' ideological and political education
}

\author{
Xiao-pu Wang \\ The Central Institute For Correctional Police \\ Baoding, China
}

\author{
Li-min Zhang \\ Humanities and Social Science of Agricultural University \\ of Hebei \\ Baoding, China
}

\author{
Qiu-ying Song \\ The Central Institute For Correctional Police \\ Baoding, China
}

\begin{abstract}
In the new period, college students' ideological and political education in should give full play to the role of excellent traditional culture, which is helpful for students to form good morals and right values. Based on this, this paper expounds the connotation and characteristics of traditional culture, and then studies the status quo of excellent traditional culture in ideological and political education and the effect of excellent traditional culture on the ideological and political education for college students. It is hoped that the students can draw the nutrition from excellent traditional culture to improve effectiveness of ideological and political education.
\end{abstract}

Keywords: excellent traditional culture; college students; ideological and political education; effect

\section{INTRODUCTION}

As the basic work of socialist spiritual civilization construction, college students' ideological and political education plays a spiritual and dynamic role in the health and rapid development of socialism; meanwhile it also plays an important role in shaping spiritual pillar of Chinese nation. However, the progress of science and technology and the popularity of network bring diversification of ideology and culture. The collision between positive and negative thoughts puts forward new challenges to college students' ideological and political education work ${ }^{[1-2]}$. The contemporary college students have problems in moral and moral issues, for example, serious standard thought, realistic value goal, weak sense of responsibility, complex moral sense, the behavioral and cognitive inconsistency and so on $^{[3-}$ ${ }^{5]}$. With the further development of reform and opening up, in the field of ideology, Chinese traditional culture is more concentrated. At the national propaganda work conference, president $\mathrm{Xi}$ pointed out that Chinese traditional culture is our deepest soft power ${ }^{[6]}$. Therefore, how to integrate the excellent traditional culture into ideological and political education of college students, and give full play to the out- standing role of traditional culture is an important practical issue.

\section{The connotation and characteristics of traditional culture}

As a form of idea, culture is always in the process of change and integration, so it is not the culture that appeared in all history can be called traditional culture. Only those who have important value and have the vitality of life can be accumulated, preserved, continue down, become an important part of future culture, which is called the traditional culture. It is profound, has a long history, after several years of development and evolution has formed a stable, ambitious, outstanding cultural system, including Confucianism, Taoism, Legalism, Buddhist doctrine, calligraphy, clothing, medicine, astronomy, geography and so on.

Chinese traditional culture has eight essences: unity consciousness of national standpoint, people-oriented of governing philosophy, harmonious will of social order construction, advocate righteousness in handling ethical relationship, self - striving spirit on the career attitude, moderate selection in solving contradiction, personal ideal pursuit of the ethical philosophy and social ideal pursuit of "Welloff Datong, ${ }^{,[7-9]}$. The eight essences are the spiritual power of contemporary college students. Under the background of economic globalization, urbanization, international democratization, traditional Chinese culture take its essence, foster strengths and circumvent weaknesses and has the following characteristics: strong openness and inclusiveness, strong vitality and cohesion, value the morals.

\section{The status quo of excellent traditional culture in Ideological and Political Education}

College students are the future of motherland and are Chinese dream practitioner. To strengthen the traditional cultural awareness of college students is of great significance for college students' ideological education. In recent years, with the diversification of culture class, they have some knowledge to the traditional culture. But there are still 
some problems. The China Times has carried on field investigation to university student's traditional cultural cognition awareness degree. The result showed that $60 \%$ of students have understanding of traditional culture; $45 \%$ can recite ancient poetry; those think that traditional culture would be useful for ideological and political education accounted for only $20 \%$. There are some differences in traditional education between different universities, but the overall contemporary college students' awareness of the traditional culture is still not enough.

Moreover, college students' ideological and political education is lack of the application of excellent traditional cultural resources. At present, many colleges and universities has not yet formed perfect college Chinese excellent traditional culture education system. College students gain ideological and political education mainly through the ideological and political theory course. In addition, in daily ideological and political education for college students, college students' ideological and political education workers mostly just propose some relatively broad specifications and requirements for students and carry out our work when they appear some problems. Rarely can the Chinese excellent traditional culture be consciously integrated into daily ideological and political work and learning.

In brief, the status of excellent traditional culture in college students' ideological and political education is not optimistic. From the perspective of students themselves, they lack cognition of traditional culture, lack concept of traditional virtue; from the perspective of teachers, organic combination level of traditional culture and ideological and political education is not high; they rely too much on classroom teaching method.

\section{Effect of excellent traditional culture on college stu- dents' ideological and political education}

Grasping the era value and rich connotation of excellent traditional culture accurately, drawing the spiritual power of college students' ideological and political education from excellent traditional culture and giving full play to the role of excellent traditional culture are important topics in current practice.

The effect of excellent traditional culture on ideological and political education is mainly manifested in four aspects: help students to establish a correct outlook on life, world outlook and values ; promote college students patriotism education ; develop college students a good ideological and moral cultivation; improve effectiveness of ideological and political education work. These four aspects interact with each other, promote each other, and complement each other, as shown in figure 1.

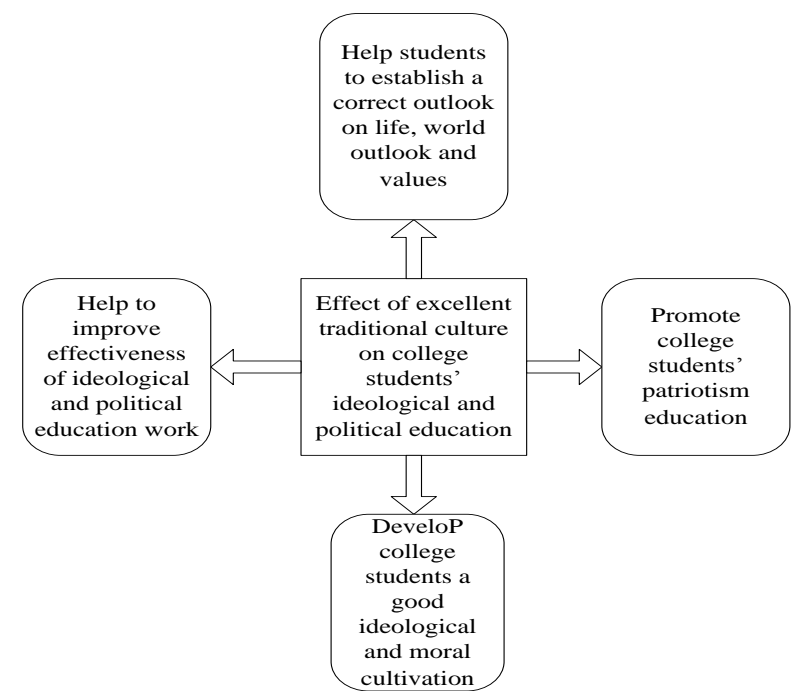

Fig. 1: Effect of excellent traditional culture on college students' ideological and political education

\subsection{Help students to establish a correct outlook on life, world outlook and values}

Helping college students to establish a correct outlook on life, world outlook and values is the core content of ideological and political education in colleges and universities. In this money centered and rapid developed society, some college students lacking self-control have money worship, hedonism, seeking nothing but profits, poor psychological quality and etc. Modern college students' value outlook is gradually becoming ripe, and its formation and development are influenced by various factors. Therefore, take full advantage of the excellent Chinese traditional culture to guide a good outlook on life, world outlook and values formation. China's outstanding traditional culture emphasizes the "What you do not wish yourself, do not do onto others", self-cultivation and governing country, valuing justice above material gains, proactive spirit; and advocates students to be modest and prudent, pay attention to etiquette, insist on collectivism in the process of self value realization. It cultivates positive, progressive, innovative, indomitable spirit and enhances students' emotional sentiment and inspires them to experience the true meaning of life, so as to improve their personality and help college students to establish the correct life view, world view and value view.

\subsection{Promote college students' patriotism education}

Patriotism is the spiritual pillar of Chinese civilization, and it is the basic content of ideological and political education for college students. Chinese nation has withstood the hardships of invasion, turmoil and other hardships in the history development, and has formed the misery consciousness of "taking the world as its own responsibility". However, in a time when the cultural diversity and the style of life are complex, the contents of patriotism will 
change with the pace of social development and progress. Some students think about patriotism is outdated in a time of peace and some militant demonstrate or damage goods, which distorts and misunderstands the nature of patriotism. Carrying forward the Chinese excellent traditional culture and national spirit education will help strengthen the cohesion, solidarity and vitality of Chinese nation during the period of peace. The Chinese national spirit contained in the traditional culture is the important factor to cultivate and stimulate national self-esteem and self-confidence and establish the national pride. By China's outstanding cultural heritage, it can promote college students' to transform emotional patriotism rational to patriotic action, to set up the lofty historical mission and sense of responsibility and do what little one can to help for the construction of socialist modernization.

\subsection{Develop college students a good ideological and moral cultivation}

Actively cultivate one's morality theory of Chinese excellent traditional culture can improve college students' ideological and moral and perfect their personality and quality. As a state of ceremonies, more than 5000 years of civilization history precipitated many theories about morality and then formed the traditional virtues of the Chinese nation. "Inclusively for from a son of heaven to commons, self-discipline serves as a foundation", "As heaven is moving vigorously, gentlemen should strive constantly to become stronger", "Do not do to others what you do not want done to yourself", "Respect for elders and care for the young", "fear every man his mother and his father" and other ideas inspire generations of all the children of Yellow Emperor strengthen their own moral self-cultivation and cultivate feelings of love. The moral concept has a certain degree of distortion in the fierce and brutal competition in society. Some contemporary college students' personality, defiant, materialistic hinder their healthy growth. Actually, the excellent traditional cultures define the contemporary Chinese most basic value orientation and behavior criterion. Combining with present spiritual civilization construction, traditional culture made the brilliant generalization of students' moral qualities and qualities. Emphasize the selfcultivation, train noble morality and moral personality, promote self-reliance enterprising spirit, advocate courtesy and to be strict with oneself and lenient towards others. Those can refine college students' healthy personality, cultivate students' physical and mental and purify their soul.

\subsection{Improve effectiveness of ideological and political education work}

Absenteeism, late and leave early phenomenon are common in ideological and political education in colleges and universities. Students who choose ideological and political class are getting fewer and fewer and they become unique in the campus. There is a conflict between the nature of education and these phenomena. As a compulsory course, the attitude of students to ideological and political class is worth pondering. The reason may be that the teaching mode of ideological and political education system in colleges is different from the teaching methods which students' desire in the information age. College students' ideological and political education has a certain role, but the effect is unsatisfactory. Many college students do not agree with the way of education and they need to be flexible that they can do what they want. Chinese traditional culture contains the concern of life and universe, the understanding of people and life; it emphasizes the value and needs of people and pay attention to the development and perfection of people. Therefore, we should integrate Chinese traditional culture into ideological and political education in colleges, because the excellent Chinese traditional culture has a stronger penetration and influence than other media. Poetry, Qu $\mathrm{Fu}$ and other cultural resources can as the starting point of the ideological and political education work and they can inspire students' wisdom when learning Chinese excellent traditional culture. Finally, it will improve the effectiveness of Ideological and political education for college students.

\section{Conclusions}

In recent years, the ideological and political education work follow the pace of the times, and achieved certain results, and play a positive role in reform and development of the economic society and colleges. But there are still some problems. Chinese excellent traditional culture with its profound and rich connotation advocates patriotism, moral sense of propriety and spirit of unremitting selfimprovement struggle and then it has positive effect on the improvement of College Students' moral quality. Therefore, how to realize the combination of excellent traditional culture and the college students' ideological and political education is the practical problem that needs to be studied in the present ideological and political education work. 


\section{References}

[1] Guosheng Zhang. The use of excellent traditional culture in the ideological and political education of college students [D].Master's thesis of Central China Normal University, 2014.

[2] Wei Zhang. Significance of traditional culture in ideological education on college students [D].Master's thesis of Shan Dong University, 2010.

[3] Haohui Pan. Theory of Chinese excellent traditional culture meaning and application in the ideological and political education [D].Master's thesis of He Nan University, 2014

[4] Qin Wang. Chinese excellent traditional culture and ideological and political education in universities [D].Master's thesis of Nan Chang University, 2012.

[5] Miao Zhu. Reflection on the excellent traditional culture into the ideological and political education $[\mathrm{J}]$.
School party construction and ideological education,2014 (12) :37-38.

[6] Xinhua Liu. Chinese excellent traditional culture and ideological and political education for college students [J]. Journal of China Three Gorges University (humanities and social science edition),2014 (32):10-12.

[7] Jianghong Zhu, Qiyun Liao.The optimization effect of Chinese traditional culture on the ideological and Political Education [J]. Journal of Social Sciences in Shanxi College of higher learning,2015,27 (4) :105-107.

[8] Yuepeng Sun, Ting Li.Strategies to achieve the value of excellent traditional culture in Ideological and Political Education [J]. China western science and technology, 2014 (1) : 3.

[9] Weiwei Yang. The application of Chinese traditional excellent culture in Ideological and political education for College Students [J]. Journal of Qiqihar Medical School, 2012 (1). 